\title{
HLA Class I Histocompatibility Antigen, A-2 Alpha Chain
}

National Cancer Institute

\section{Source}

National Cancer Institute. HLA Class I Histocompatibility Antigen, A-2 Alpha Chain. NCI Thesaurus. Code C16691.

HLA class I histocompatibility antigen, A-2 alpha chain (365 aa, $\sim 41 \mathrm{kDa}$ ) is encoded by the human HLA-A gene. This protein is involved in antigen presentation. 